\title{
Cycloartane-type glycosides from Astragalus brachycalyx FISCHER and their effects on cytokine release and hemolysis
}

\author{
Behnaz Aslanipour $^{\mathrm{a}}$, Derya Gülcemal ${ }^{\mathrm{b}}$, Ayşe Nalbantsoy ${ }^{\mathrm{a}}$, Hasan Yusufoglu ${ }^{\mathrm{c}}$, Erdal Bedir ${ }^{\mathrm{d}, *}$ \\ a Department of Bioengineering, Faculty of Engineering, Ege University, Bornova, 35100, Izmir, Turkey \\ b Department of Chemistry, Faculty of Science, Ege University, Bornova, 35100 Izmir, Turkey \\ ${ }^{c}$ Department of Pharmacognosy, College of Pharmacy, Prince Sattam Bin Abdulaziz University, 11942 Al-Kharj, Saudi Arabia \\ d Department of Bioengineering, Faculty of Engineering, Izmir Institute of Technology, Urla, 35430 Izmir, Turkey
}

\section{A R T I C L E I N F O}

\section{Keywords:}

Astragalus brachycalyx

Fabaceae

Saponins

Cycloartane

Cytokine stimulation

Hemolytic activity

\begin{abstract}
A B S T R A C T
Two new tridesmosidic cycloartane-type triterpene glycosides (1 and 2) were isolated from the methanolic extract of the roots of Astragalus brachycalyx FISCHER (A. brachycalyx) along with ten (3-12) known cycloartanetype triterpene glycosides. Structures of the new compounds were established as $3-O-\beta$-D-xylopyranosyl-6-O- $\beta$-Dglucopyranosyl-16-O- $\beta$-D-glucopyranosyl-3 $\beta, 6 \alpha, 16 \beta, 24(S)$-25-pentahydroxycycloartane (1), 3-O-[ $\alpha$-L-arabinopyranosyl-( $1 \rightarrow 2)$ - $\beta$-D-xylopyranosyl]-6- $O$ - $\beta$-D-glucopyranosyl-16- $O$ - $\beta$-D-glucopyranosyl-3 $\beta, 6 \alpha, 16 \beta, 24(S)-25$-pentahydroxycycloartane (2), by using 1D and 2D-NMR techniques and mass spectrometry.

In vitro immunomodulatory effects and hemolytic activities of the new saponins (1 and 2) and acetylated form of 1 (1a) were studied together with the $\mathrm{BuOH}$ and $\mathrm{MeOH}$ extracts of Astragalus brachycalyx. The results have proven that tridesmosidic Astragalus cycloartanes are noteworthy immunomodulatory compounds via induction of cytokine production, namely IL- 2 and IFN- $\gamma$. The test compounds also resulted slight hemolysis at very high doses substantiating a safer profile compared to the positive control QS-21.
\end{abstract}

\section{Introduction}

The genus Astragalus L., belonging to the family of Fabaceae with more than 3.000 species of herbs and small shrubs, is broadly distributed in Mountainous areas throughout the world, mostly in Asia. Iran alone, being the richest center of Astragalus habitation, shelters more than 850 species, 527 of which are endemic in the flora of Iran (Ranjbar and Karamian, 2002; Massoumi 1998). The crude drugs prepared from Astragalus roots are used for treating some illnesses such as leukemia, respiratory infections and diabetes in Iranian folk medicine. The phytochemical studies performed on Astragalus species mainly resulted in the isolation of a series of oleanane- and cycloartane-type triterpene glycosides (Bedir et al., 1998, 1999; Gülcemal et al., 2011; Horo et al., 2010; Polat et al., 2010; Savran et al., 2012). Some bioactive compounds from Astragalus species are reported to contain anticancer and immunostimulatory activities (Rios and Waterman, 1997; Bedir et al., 2000). Li (2000) showed that polysaccharides from Astragalus mongholicus, consisting of glucose and arabinose moieties, increase not only the synthesis of RNA, DNA and protein but also the specific antibody formation in mouse spleen. To discover the contributory role of immunomodulatory effects of saponins, the lymphocyte stimulation test was performed on eight cycloartane-type saponins isolated from Astragalus melanophrurius (Calis et al., 1997). It was shown that the higher concentrations of the test compounds $(100-200 \mu \mathrm{g} / \mathrm{mL})$ had inhibitory effect on thymidine incorporation. In another study, the effects of nineteen cycloartane-type triterpene glycosides, isolated from Astragalus species, were investigated on macrophage activation utilizing a transcription factor-based bioassay for the activation of Nuclear Factor Kappa B (NF-kB) in a human macrophage/ monocyte cell line. The only compound exhibiting activity was astragaloside I, increased NF-кB-directed luciferase expression up to 65\%. It also increased the mRNA expression of inflammatory cytokines, such as IL- $1 \beta$ and TNF- $\alpha$ (Bedir et al., 2000). Verotta et al. (2001) reported the results of their study based on the effect of cycloartane saponins obtained from Astragalus peregrinus as modulators of lymphocyte proliferation. The compounds showed stimulation in proliferation of mouse splenocytes, and were not cytotoxic. IL-2, a cytokine produced by activated $\mathrm{T}$ cells, is proven to be a powerful immunostimulatory and antineoplastic agent. Yesilada et al. (2005) reported that astragaloside VII (AST VII), a tridesmosidic glycoside of cycloastragenol, was the most remarkable compound in regards to induction of IL-2 production (\%139.6). In a continuation study, Nalbantsoy et al. (2011) evaluated

\footnotetext{
* Corresponding author.

E-mail address: erdalbedir@iyte.edu.tr (E. Bedir).
} 
adjuvant and hemolytic effects of IL-2 stimulating Astragalus compounds. AST VII and Macrophyllosaponin B (MAC B) generated important specific antibody and cellular response against BSA in mice, and both compounds were proposed to be potent immunoregulatory agents to be used in vaccine formulations as adjuvants. In the case of hemolysis, AST VII showed very low $(0.54 \%)$ hemolytic index at the highest treatment concentration of $500 \mu \mathrm{g} / \mathrm{mL}$ (Nalbantsoy et al., 2012).

Although Iran inhabitates many endemic Astragalus species, there is no detailed phytochemical study reported on Iranian Astragalus plants. Here we reported the isolation and structure elucidation of two new cycloartane-type triterpene glycosides (1-2) along with ten known cycloartane-type triterpene glycosides (3-12) from the methanolic extract of $A$. brachycalyx, an Iran-Turan endemic. Additionally, the methanol and butanol extracts of $A$. brachycalyx, and the new saponins (1 and 2) together with 1a were evaluated for in vitro cytokine release (IL-2, IL$17 \mathrm{~A}$ and IFN- $\gamma$ ) from human whole blood using ELISA. Apart from this, hemolytic activities of the same samples were studied in human red blood cells.

\section{Results and discussion}

The molecular formula of 1 was determined as $\mathrm{C}_{47} \mathrm{H}_{80} \mathrm{O}_{19}$ from HRESIMS $\left(m / z 987.4962[\mathrm{M}+\mathrm{K}]{ }^{+}\right)$and the ${ }^{1} \mathrm{H}$ and ${ }^{13} \mathrm{C}$ NMR data. The ${ }^{1} \mathrm{H}$ NMR spectrum of 1 showed signals due to a cyclopropane methylene at $\delta 0.49$ and 0.19 (each $1 \mathrm{H}, \mathrm{d}, J=3.9 \mathrm{~Hz}$ ), six tertiary methyl groups at $\delta 2.07,1.52(6 \mathrm{H}), 1.39,1.22,0.88$, a secondary methyl group at $\delta 1.00(\mathrm{~d}, 6.5)$ and four methine proton signals at $\delta 4.39$ (m), $3.97(\mathrm{~m}), 3.70(\mathrm{~m})$ and $3.53(\mathrm{dd}, J=11.6,4.3 \mathrm{~Hz})$, which were indicative of secondary alcoholic functions. The NMR data of the aglycone moiety of 1 were in good agreement with those reported for cyclocanthogenin (Bedir et al., 1998) with glycosidation shifts for C-3 ( $\delta$ 88.5), C-6 ( $\delta$ 79.9) and C-16 ( $\delta$ 82.4). Furthermore, the ${ }^{1} \mathrm{H}$ NMR spectrum of 1 clearly showed three anomeric proton doublets at $\delta 4.89$ (d, $J=7.7 \mathrm{~Hz}), 4.85$ (d, $J=7.5 \mathrm{~Hz}$ ) and $4.73(\mathrm{~d}, J=7.7 \mathrm{~Hz}$ ) in the downfield region, indicative of three $\beta$-linked sugar units. These correlated to C-atom signals at $\delta 105.1,107.4$ and 106.3, respectively, in the HSQC spectrum.

The HMQC, HMBC and COSY data led to identify these sugar units as one $\beta$-xylopyranosyl and two $\beta$-glucopyranosyl units, all of which were also suggested to have a D-configuration based on the biogenetic considerations derived from Astragalus cycloartanes (Bedir et al., 1998, 1999; Calis et al., 1997; Gülcemal et al., 2011; Horo et al., 2010; Polat et al., 2010; Savran et al., 2012) and the optical rotation data of each isolated sugar.

The HMBC correlations between the proton signal at $\delta 4.85\left(\mathrm{H}-1_{\mathrm{xyl}}\right)$ and the carbon resonance at $\delta 88.5$ (C-3), the proton signal at $\delta 4.89$ (H$1_{\text {glcI }}$ ) and the carbon resonance at $\delta 79.9(\mathrm{C}-6)$ and the proton signal at $\delta$ $4.73\left(\mathrm{H}-1_{\text {glcII }}\right)$ and the carbon resonance at $\delta 82.4$ (C-16) allowed us to determine the linkage site of the sugar units. Thus, the new compound 1 was elucidated as 3-O- $\beta$-D-xylopyranosyl-6-O- $\beta$-D-glucopyranosyl-16-O$\beta$-D-glucopyranosyl-3 $\beta, 6 \alpha, 16 \beta, 24(S)-25$ pentahydroxycycloartane.

The HRESIMS data of 2 indicated a molecular formula of $\mathrm{C}_{52} \mathrm{H}_{88} \mathrm{O}_{23}$ ( $m / z 1103.5646$ calcd.) that was deduced from the ion peak at $m / z$ $1103.5648\left(\mathrm{C}_{52} \mathrm{H}_{88} \mathrm{O}_{23} \mathrm{Na}\right)$. The ${ }^{1} \mathrm{H}$ NMR and ${ }^{13} \mathrm{C}$ chemical shifts of the aglycone moiety of $\mathbf{2}$ were superimposable with those of $\mathbf{1}$. Moreover, for the sugar portion of $\mathbf{2}$ in comparison with that of $\mathbf{1}$, the occurrence of an additional sugar unit was observed. The ${ }^{1} \mathrm{H}$ NMR showed signals for four anomeric protons at $\delta 5.22$ (d, $J=6.6 \mathrm{~Hz}$ ), 4.91 (d, $J=7.7 \mathrm{~Hz}), 4.86(\mathrm{~d}, J=6.8 \mathrm{~Hz})$ and $4.75(\mathrm{~d}, J=7.6 \mathrm{~Hz})$, which showed correlations in the HSQC spectrum with the anomeric carbon signals at $\delta 106.7,105.4,105.4$ and 106.6, respectively. These data, in combination with HSQC, HMBC, COSY correlations, showed that 2 differed from 1 only by the presence of an additional $\alpha$-arabinopyranosyl unit. Therefore, on the basis of the HMBC correlation between the proton signal at $\delta 5.22\left(\mathrm{H}-1_{\text {ara }}\right)$ and the carbon resonance at $\delta 83.5$ $\left(\mathrm{C}-2_{\mathrm{xyl}}\right)$ the arabinose was located at $\mathrm{C}-2_{\mathrm{xyl}}$. The D configuration of xylose and glucose and L configuration of arabinose units were established after hydrolysis of saponin fraction $\mathrm{P}$ of $A$. brachycalyx and confirmation by the optical rotation data of each isolated sugar.

Consequently, compound 2 was identified as 3-O-[ $\alpha$-L-arabinopyranosyl-(1 $\rightarrow 2$ )- $\beta$-D-xylopyranosyl]-6- $O$ - $\beta$-D-glucopyranosyl-16- $O-\beta$-Dglucopyranosyl-3 $\beta, 6 \alpha, 16 \beta, 24(S)-25$-pentahydroxycycloartane.

Additionally, one known cycloartane-type triterpene, cycloastragenol (3) (Bedir et al., 1999) and nine known cycloartane-type triterpene glycosides, Astragaloside IV (4) (Kitagawa et al., 1983a), cyclocanthoside E (5) (Isaev et al., 1992), astragaloside VIII (6) (Kitawaga et al., 1983b), 3-O- $\beta$-D-xylopyranosyl-6,25-di-O- $\beta$-D-glucopyranosyl$3 \beta, 6 \alpha, 16 \beta, 24(S), 25$-pentahydroxycycloartane (7) (Gülcemal et al., 2011) cyclocephaloside I (8) (Bedir et al., 1998), astrachrysoside A (9) (Gan et al., 1986), cycloaraloside D (10) (Isaev, 1991), oleifolioside A (11) and oleifolioside B (12) (Ozipek et al., 2005) were isolated.

IL-2, with a critical role in the immune system by assisting immature $\mathrm{T}$ cells to differentiate into regulatory $\mathrm{T}$ cells, effector $\mathrm{T}$ cells or memory $\mathrm{T}$ cells, helps the body to fight against infectious diseases directly or indirectly (Liao et al., 2011). IFN $\gamma$, known as type II interferon, is another vital cytokine with immunostimulatory potential. It has been confirmed that IFN $\gamma$ can play a crucial role in immune response against some intracellular pathogens in diseases such as Chagas, and it coordinates a dissimilar array of cellular programs through transcriptional regulation of genes that are immunologically relevant (Ben-Asouli et al., 2002; Schroder et al., 2004). One of the most important properties of IFN $\gamma$ is on the innate and adaptive immune response against tumors and pathogens (Lin and Young, 2013). IL-17A, originally identified as a transcript from a rodent T-cell hybridoma by Rouvier et al. (1993), is the chief member of the family named IL-17A cytokine group, and one of its essential roles is induction and facilitation of pro-inflammatory responses (Aggarwal and Gurney, 2002). IL-17A inhibitors are under investigation to treat autoimmune diseases like rheumatoid arthritis, psoriasis and inflammatory bowel disease. This group of cytokine inhibitors can lead to an aberrant airway neutrophil response to allergen stimuli (Yang et al., 2008). The role of IL-17A for Th17 cells in vitiligo pathogenesis treatment has also been confirmed (Zhou et al., 2015). Concisely, IL-2, IFN $\gamma$ and IL-17A are essential cytokines with different functions for the immune system, and developing new molecules modulating them will have a potential use in therapy.

Previous studies suggest that the specific molecules turning on the cytokine gene expression is more beneficial than injectable therapeutic doses of cytokines signifying the importance of the discovery of potent immunostimulatory agents (Gillis and Williams, 1998; Oda et al., 2003; Pandey et al., 2016; Hu et al., 2016).

Astragalus derived preparations are known for their stimulatory effects on cellular and humoral immune responses. Previous studies undoubtedly pointed to induction of cytokines such as interleukins and interferons for their immunostimulatory actions (Yang et al., 2005; Nalbantsoy et al., 2011, 2012). Not only crude Astragalus preparations but also its purified polysaccharides and saponins were demonstrated immunomodulatory activity in line with previous studies (Behboudi et al., 1999; Yang et al., 2008; Nalbantsoy et al., 2012; Lai et al., 2014). Thus Astragalus species and their components deserve detailed investigation for their immunomodulatory properties.

In this study, the effects of two newly established cycloartane-type saponins (compounds 1 and 2) along with compound 1a (acetylated form of compound 1), methanol and butanol extracts of $A$. brachycalyx were studied on the human whole blood stimulated with PMA plus ionomycin for IL-2, IFN- $\gamma$ and IL-17A cytokines' release at 3 and $6 \mu \mathrm{g}$ concentrations, (Fig. 3). AST VII and QS-21 saponins were used as positive controls. At $3 \mu \mathrm{g}$ concentration, AST VII increased the level of IL-2 $(1263.2 \pm 0.89 \mathrm{pg} / \mathrm{mL}(\times 30), P<0.001)$ whereas it did not show any effect on IFN- $\gamma(283.6 \pm 0.12 \mathrm{pg} / \mathrm{mL}(\times 20), P>0.05)$ and IL$17 \mathrm{~A}(783.7 \pm 0.04 \mathrm{pg} / \mathrm{mL}(\times 20), P>0.05)$ production. However, AST VII increased the concentration of IL-2 $(1217.65 \pm 0.03 \mathrm{pg} / \mathrm{mL}$ $(\times 30), P<0.001)$ and IL-17A $(317.66 \pm 0.32 \mathrm{pg} / \mathrm{mL}(\times 20)$, 
$P<0.05)$ at $6 \mu \mathrm{g}$ with no effect on IFN- $\gamma$ production $(823.67 \pm 0.19 \mathrm{pg} / \mathrm{mL}(\times 20), P>0.05)$. QS-21 exhibited substantial effect on IFN- $\gamma(395.85 \pm 0.32 \mathrm{pg} / \mathrm{mL}, P<0.001)$ and IL-2 $(1217.02 \pm 1.07 \mathrm{pg} / \mathrm{mL}(\times 30), P<0.01)$ release at $3 \mu \mathrm{g}$ concentration. Besides, QS-21 exhibited more potency towards IL-2 and IFN- $\gamma$ stimulation $(1416.94 \pm 0.41(\times 30)$ and $399.20 \pm 0.29$ $(\times 20), \mathrm{pg} / \mathrm{mL}$, respectively) $(P<0.001)$ at $6 \mu \mathrm{g}$ concentration, whereas it did not show any effect on IL-17A concentration.

The results showed that the concentration of IL-2 was significantly increased by $1(6 \mu \mathrm{g}), 2(6 \mu \mathrm{g})$, the $\mathrm{MeOH}$ extract $(6 \mu \mathrm{g})$ and slightly with $1 \mathrm{a}(3 \mu \mathrm{g})$ compared to the control group $(P<0.01, P<0.001$ or $P<0.05)$. The IFN- $\gamma$ concentration was stimulated considerably at $3 \mu \mathrm{g}$ dose of compound $2(390.33 \pm 0.02 \mathrm{pg} / \mathrm{mL}(\times 20), P<0.001)$ possessing tridesmosidic framework with 4 sugar moieties compared to those of 1 and $1 \mathrm{a}$ with trisaccharidic nature $(P<0.01$ or $P<0.001)$. The $\mathrm{MeOH}$ extract showed a slight effect on IFN- $\gamma$ induction at $6 \mu \mathrm{g}$ $(P<0.05)$. Moreover, the concentration of IL-17A was not effected by any of the tested molecules $(P>0.05)$ in comparison to the control group.

Administraton of $\mathbf{1 a}$, the fully acetylated form of $\mathbf{1}$, resulted in altered levels of cytokine release compared to 1 at 3 and $6 \mu \mathrm{g}$ concentrations. Compound 1a showed slightly higher IL-2 induction $(1165.48 \pm 0.08 \mathrm{pg} / \mathrm{mL}(\times 30), \quad P<0.05)$ than compound 1 $(1136.47 \pm 0.01 \mathrm{pg} / \mathrm{mL}(\times 30), P>0.05)$ at $3 \mu \mathrm{g}$, whereas 1 $(1168.56 \pm 0.04 \mathrm{pg} / \mathrm{mL}(\times 30), P<0.05)$ increased the level of IL-2 in comparison to $1 \mathrm{a}(1116.84 \pm 0.2 \mathrm{pg} / \mathrm{mL}(\times 30), P>0.05)$ at $6 \mu \mathrm{g}$ concentration (Fig. 3). These results imply that more hydrophobic forms of tridesmosidic Astragalus saponins still put forth IL-2 induction at lower doses $(3 \mu \mathrm{g})$ signifying their potential use in oil based adjuvant systems. In modern vaccines, oil-in-water $(\mathrm{o} / \mathrm{w})$ emulsions are used as adjuvants safely and successfully. The most remarkable $\mathrm{o} / \mathrm{w}$ emulsions used clinically are MF59 and AS03. Both adjuvant systems include squalene at $\sim 2.5 \%(\mathrm{v} / \mathrm{v})$ in the final vaccine formulation (Fox, 2009).

Basically, the immune response is categorized in two groups based on the cytokine profile induced: Th1 or Th2. The Th1 profile is characterized by the initial production of IFN $\gamma$ and IL-12 with an effector phase of T lymphocytes producing IL-2 and IFN $\gamma$ and mediating cytotoxic activity (CTL). In contrast, Th2 responses are influenced by IL-4 with predominantly IL-5 and IL-10 producing T cells in the effector phase that drive antibody production (Nalbantsoy et al., 2011, 2012, Yang et. al., 2005). In this paper, the presented saponins were found predominantly effective on Th1 as associated with induction of IL-2 and IFN $\gamma$. Hu et al. (2016) tested the role of 5 different saponins on altering levels of IL-4, IL-10, IL-2, and IFN- $\gamma$. Their results revealed increments in IFN- $\gamma$ concentrations together with upregulation of IL-2 expression, validating our immunomodulatory findings.

Saponins cause hemolysis because of their well-known effects: cell membrane swelling due to pore formation, partial entry of extracellular $\mathrm{Ca}^{2+}$ and ceramide formation (Bissinger et al., 2014). In this study, Astragalus brachycalyx extracts and isolates were also investigated for their hemolytic activities to prove that observed immunostimulatory activities are not originating from such action. As shown in Table 3, QS21 showed a notably strong hemolytic activity in all tested concentration $(5000,500,250,125,50 \mu \mathrm{g} / \mathrm{mL}(P<0.01)$ and $25,12.5,2.5 \mu \mathrm{g}$ / $\mathrm{mL}(P<0.05)$. Moreover, AST VII exhibited slight hemolysis for $5000 \mu \mathrm{g} / \mathrm{mL}$ concentration $(P<0.05)$, while there was no hemolytic activity for the doses of 250,125, 50, 25, 12.5 and $2.5 \mu \mathrm{g} / \mathrm{mL}$ $(P>0.05)$. As it is shown in Fig. 1 , acetylated derivative 1a $(500 \mu \mathrm{g} /$ $\mathrm{mL})$ demonstrated a slight hemolytic activity $(P<0.05)$, whereas 1 did not cause any hemolysis at all tested concentrations. According to the above mentioned results, one could state that the tridesmosidic saponins of Astragalus genus are safer adjuvant candidates compared to the well-investigated QS-21 that is a strong hemolytic agent.

Consequently, our findings surely warrant further studies especially focusing on the mechanism of action and in vivo potential of the described saponins.

\section{Experimental}

\subsection{General}

Optical rotations were measured on a JASCO DIP 1000 polarimeter. The ${ }^{1} \mathrm{H},{ }^{13} \mathrm{C}$ NMR spectra as well as 2D-NMR experiments (COSY, HSQC and $\mathrm{HMBC}$ ) were obtained using $400 \mathrm{MHz}$ for ${ }^{1} \mathrm{H}$ NMR. $100 \mathrm{MHz}$ for ${ }^{13} \mathrm{C}$ NMR were measured on a Varian AS 400 Mercury spectrometer for compound 1a and compound 2, and standard Bruker program on a UltraShield Plus $500 \mathrm{MHz}$ (Bruker) (NMR Unite at the College of Pharmacy, Prince Sattam bin Abdulaziz University) spectrometer operating at $500 \mathrm{MHz}$ for proton and $125 \mathrm{MHz}$ for carbon for compound 1. The chemical shift values are reported in $\delta$ (ppm) relative to the residual solvent peak, and the coupling constants $(J)$ are reported in Hertz (Hz) and MS spectra were measured on a LC/MS High resolution Time of Flight (TOF) Agilent 1200/6530 instrument; CC, silica gel 60 (Merck); GPC (General Permeation Chromatography, Sephadex LH-20). All 2DNMR spectra were acquired in Pyridine- $d_{5}(99.50 \%$, SigmaAldrich) standard pulse sequences and phase cycling were used for COSY, HSQC and HMBC spectra.

\subsection{Plant material}

The root and stem parts of Astragalus brachycalyx FISCHER was collected from Sardasht City, Landi Sheykhan Mountain, altitude of 2400 m, West Azerbaijan Province, Iran, in August 2013, and identified by Dr. Ali-Asghar Massoumi (botanist) in Research Institute of Forests and Rangelands. A voucher specimen (Tehran 19536) was deposited at Herbarium Research and The Application Center in Research Institute of Forests and Rangelands, Tehran, Iran.

\subsection{Extraction and isolation}

Air-dried and powdered roots of A. brachycalyx (900 g) was extracted with $\mathrm{MeOH}(3 \times 2.5 \mathrm{~L})$ for 5 days under reflux. After filtration, the solvent was removed by rotary evaporation affording a crude extract of $98 \mathrm{~g}$. The extract was dissolved in water $(700 \mathrm{~mL})$ and successively partitioned with $n$-hexane $(4 \times 300 \mathrm{~mL}), \mathrm{CH}_{2} \mathrm{Cl}_{2}(4 \times 300 \mathrm{~mL})$, EtOAc $(4 \times 300 \mathrm{~mL})$, and $n$-BuOH $(4 \times 300 \mathrm{~mL})$. After evaporation the $n$-BuOH extract $(20.71 \mathrm{~g})$ was applied to Vacuum Liquid Chromatography (VLC) using reversed-phase silica (Lichroprep RP-18, 25-40 $\mu \mathrm{m}, 600 \mathrm{~g}$ ) employing $\mathrm{H}_{2} \mathrm{O}-\mathrm{MeOH}$ (90:10; 80:20; 60:40; 50:50; $40: 60 ; 20: 80$ ) and $\mathrm{MeOH}$ to give 23 main fractions (Fr. A-W). Fraction M (5.61 g) was applied to an open column chromatography using normal-phase silica gel $(23 \times 1200 \mathrm{~mm}, 600 \mathrm{~g})$ as stationary phase. The column was started and continued with $\mathrm{CHCl}_{3}-\mathrm{MeOH}-\mathrm{H}_{2} \mathrm{O}$ mixtures (90:10:1; 85:15:1.5; 80:20:2; 75:25:2.5; 70:30:3; 61:32:7; $64: 50: 10)$ to provide 3259 fractions. Fractions M-800-970 (56 mg) were combined and fractionated over reversed-phase material (Lichroprep RP-18, 25-40 $\mu \mathrm{m}, 20 \times 130 \mathrm{~mm}, 15 \mathrm{~g}$ ) eluting with $\mathrm{MeOH}-\mathrm{H}_{2} \mathrm{O}$ (50:50) mixture to afford compounds $3(8.4 \mathrm{mg})$ and $4(11 \mathrm{mg})$. Fractions M-1200-1450 (379.9 mg) were combined and further separated over normal phase silica gel $(23 \times 450 \mathrm{~mm}, 60.6 \mathrm{~g})$ using a stepgradient of EtOAc-MeOH- $\mathrm{H}_{2} \mathrm{O}$ (100:10:5; 100:15:7.5; 100:17.5:13.5; $100: 20: 15 ; 100: 25: 20)$ to give 489 subfractions. Subfractions $130-168$ (38.1 mg) were combined and subjected to column chromatography by using reversed-phase material (Lichroprep RP-18, 25-40 $\mu \mathrm{m}$, $20 \times 100 \mathrm{~mm}, 10.3 \mathrm{~g}$ ) and isocratic $\mathrm{MeOH}-\mathrm{H}_{2} \mathrm{O}$ mobile phase system (5:5) to give 5 (9.5 mg). Subfractions 171-179 (25 mg) were combined and chromatographed over normal phase silica gel $(23 \times 450 \mathrm{~mm}$, 70 g) employing with $\mathrm{CHCl}_{3}-\mathrm{MeOH}-\mathrm{H}_{2} \mathrm{O}$ (90:10:1; 80:20:1; 80:20:2; $70: 30: 3$; 61:32:7) mixtures and methanol to afford compounds 2 $(18 \mathrm{mg}$ ) and $6(4.4 \mathrm{mg})$. Subfractions 279-302 (90 mg) were combined and subjected to column chromatography by using normal-phase silica gel $(20 \times 260 \mathrm{~mm}, 22.2 \mathrm{~g})$ eluting with $\mathrm{CHCl}_{3}-\mathrm{MeOH}-\mathrm{H}_{2} \mathrm{O}$ solvent system $(85: 15: 1.5 ; 80: 20: 2 ; 75: 25: 2.5 ; 70: 30: 3 ; 61: 32: 7 ; 64: 50: 10)$ to 


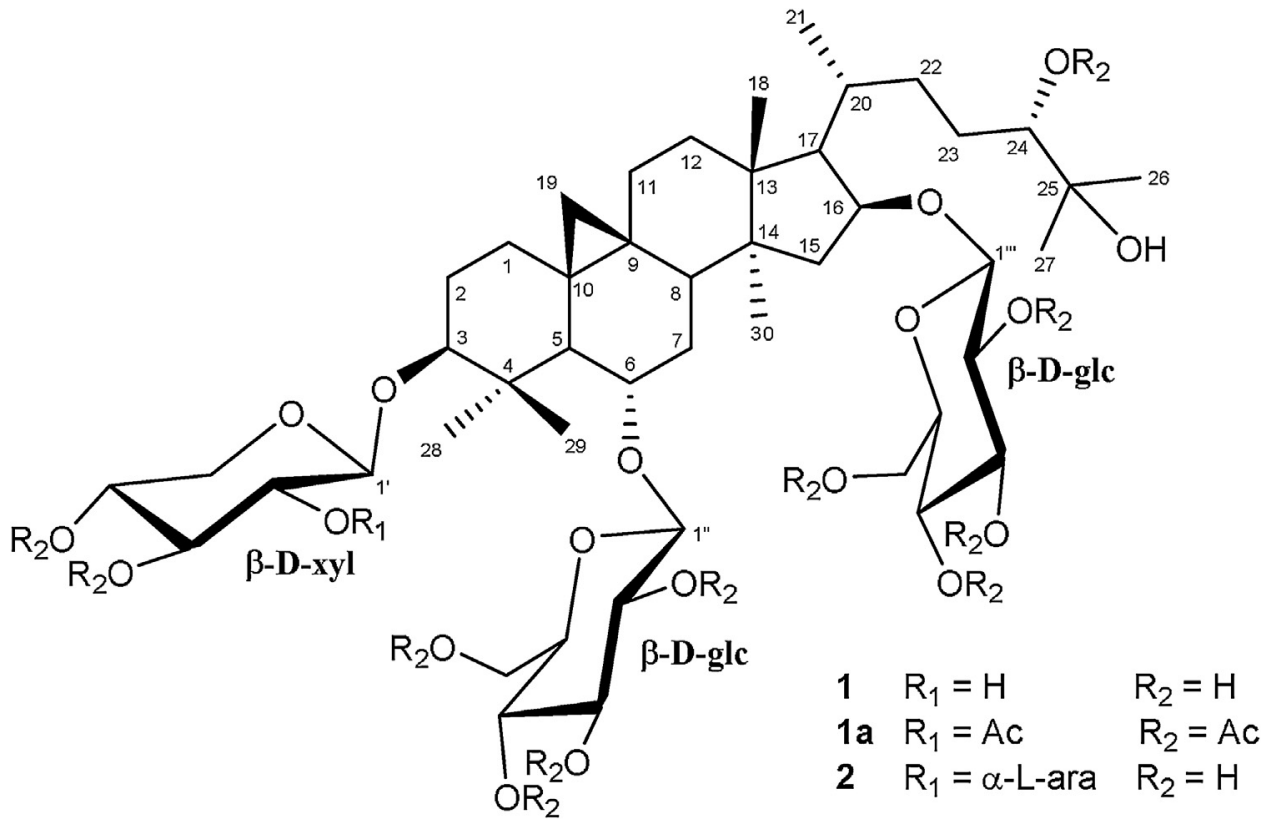

Fig. 1. Structures of compounds 1, 1a and 2.

yield a mixture including two compounds ( $80 \mathrm{mg}$ ). As the open column chromatography was not successful to separate these two metabolites due to their almost identical polarity, the mixture was acetylated using acetic anhydride and pyridine. Prior to acetylation, the mixture was analyzed by ${ }^{1} \mathrm{H}$-NMR to make sure that no acetyl group was present for both compounds. After acetylation, the mixture was applied to column chromatography by using normal-phase silica gel $(20 \times 260 \mathrm{~mm}$, $22.2 \mathrm{~g}$ ) eluting with $\mathrm{CHCl}_{3}-\mathrm{CH}_{3} \mathrm{COCH}_{3}$ (80:20; 70:30; 60:40; 50:50; 40:60) to yield 1a (65 mg) and $7 \mathbf{a}(5 \mathrm{mg})$. Compounds 1a and 7a were hydrolyzed with $0.5 \mathrm{~N} \mathrm{NaOH}$. After neutralization, reaction mixtures were applied to silica gel column $(30 \times 1000 \mathrm{~mm}, 48 \mathrm{~g})$ with the solvent system $\mathrm{CHCl}_{3}-\mathrm{CH}_{3} \mathrm{COCH}_{3}(60: 40 ; 50: 50 ; 40: 60 ; 30: 70)$ affording 1 (48 $\mathrm{mg}$ ) and 7 (2.5 mg). The spectra and spectral data of 1a were provided to support structural determination of 1 (see Supplementary file). Fractions M-2687-2900 (1.0 g) were combined and rechromatographed over an open column chromatography using silica gel ( $35 \times 120 \mathrm{~mm}, 350 \mathrm{~g}$ ) as stationary phase. Elution was performed with $\mathrm{CHCl}_{3}-\mathrm{MeOH}-\mathrm{H}_{2} \mathrm{O}$ (90:10:1; 80:20:1; 80:20:2; 70:30:3; 61:32:7) to give compounds 8 (25.5 $\mathrm{mg})$ and $9(40.8 \mathrm{mg})$. The main fraction $\mathrm{O}(2.70 \mathrm{~g})$ was fractionated over a silica gel column $(30 \times 1000 \mathrm{~mm}, 390 \mathrm{~g})$. Elution was carried out with $\mathrm{CHCl}_{3}-\mathrm{MeOH}-\mathrm{H}_{2} \mathrm{O}$ (85:15:1.5; 80:20:2; $75: 25: 2.5 ; 70: 30: 3)$ to yield 1110 fractions. Fractions 0-90-110 (307 mg) were subjected to column chromatography by using normalphase silica gel $(35 \times 120 \mathrm{~mm}, 150 \mathrm{~g})$ eluting with $\mathrm{CHCl}_{3}-\mathrm{MeOH}-\mathrm{H}_{2} \mathrm{O}$ solvent system (90:10:1; 80:20:2; 70:30:3; 61:32:7) to yield 10 (40.3). Fractions 0-138-210 (100 mg) were applied to silica gel column $(35 \times 120 \mathrm{~mm}, 50 \mathrm{~g})$ with the solvent system $\mathrm{CHCl}_{3}-\mathrm{MeOH}-\mathrm{H}_{2} \mathrm{O}$ (90:10:1; 80:20:2; 70:30:3; 61:32:7) yielding 11 (9.2). Fractions N-900943 (107 mg) were subjected to column chromatography by using normal-phase silica gel $(35 \times 120 \mathrm{~mm}, 55 \mathrm{~g})$ eluting with $\mathrm{CHCl}_{3^{-}}$$\mathrm{MeOH}-\mathrm{H}_{2} \mathrm{O}$ solvent system (90:10:1; 80:20:2; 70:30:3; 61:32:7) to yield $12(6.2)$

3.3.1. 3-O- $\beta$-D-xylopyranosyl-6,16-di-O- $\beta$-D-glucopyranosyl-

$3 \beta, 6 \alpha, 16 \beta, 24(S)-25$ pentahydroxycycloartane (1)

Amorphous white solid; $\mathrm{C}_{47} \mathrm{H}_{80} \mathrm{O}_{19} ;[\alpha]^{19}{ }_{\mathrm{D}}+14.6$ (c $\left.0.1 \mathrm{MeOH}\right)$; IR $\nu_{\max }^{\mathrm{KBr}} \mathrm{cm}^{-1}$ : $3435(>\mathrm{OH}), 2930(>\mathrm{CH})$; for ${ }^{1} \mathrm{H}$ and ${ }^{13} \mathrm{C} \mathrm{NMR}$ (Pyridine- $\mathrm{d}_{5}, 500 \mathrm{MHz}$ ) data of the aglycone moiety and the sugar portion see Tables 1 and 2, respectively; HRESIMS $m / z$ 987.4962 [M $+\mathrm{K}^{+}$(calcd. for $\mathrm{C}_{47} \mathrm{H}_{80} \mathrm{O}_{19} \mathrm{~K}, 987.4960$ ) (positive mode).
Table 1

${ }^{13} \mathrm{C}$ and ${ }^{1} \mathrm{H}$ NMR data $(\mathrm{J}$ in $\mathrm{Hz}$ ) of the aglycone moieties of $\mathbf{1}$ and $2(400 \mathrm{MHz}$ for 2 , and $500 \mathrm{MHz}$ for $1, \delta \mathrm{ppm}$, in Pyridine- $\mathrm{d}_{5}$ ).

\begin{tabular}{|c|c|c|c|c|}
\hline \multirow[t]{2}{*}{$\mathrm{C} / \mathrm{H}$} & \multicolumn{2}{|l|}{1} & \multicolumn{2}{|l|}{2} \\
\hline & $\delta_{\mathrm{C}}$ & $\delta_{\mathrm{H}}(J$ in $\mathrm{Hz})$ & $\delta_{\mathrm{C}}$ & $\delta_{\mathrm{H}}(J$ in $\mathrm{Hz})$ \\
\hline 1 & 32.1 & $1.58, \mathrm{~m} ; 1.23, \mathrm{~m}$ & 32.4 & $1.61, \mathrm{~m} ; 1.31, \mathrm{~m}$ \\
\hline 2 & 30.0 & $2.36, \mathrm{~m} ; 1.96, \mathrm{~m}$ & 30.2 & $2.29, \mathrm{~m} ; 1.96, \mathrm{~m}$ \\
\hline 3 & 88.5 & 3.53 , dd $(11.6,4.3)$ & 88.1 & 3.48 , dd $(11.4,4.0)$ \\
\hline 4 & 42.4 & - & 42.8 & - \\
\hline 5 & 52.3 & $1.90, \mathrm{~d}(9.1)$ & 52.5 & $1.90, \mathrm{~d}(8.0)$ \\
\hline 6 & 79.9 & $3.70, \mathrm{~m}$ & 79.4 & $3.74, \mathrm{~m}$ \\
\hline 7 & 34.6 & $2.36, \mathrm{~m} ; 1.75, \mathrm{~m}$ & 34.6 & $2.31, \mathrm{~m} ; 1.87, \mathrm{~m}$ \\
\hline 8 & 46.2 & $1.76, \mathrm{~m}$ & 45.5 & $1.83, \mathrm{~m}$ \\
\hline 9 & 21.0 & - & 21.5 & - \\
\hline 10 & 28.5 & - & 28.7 & - \\
\hline 11 & 26.0 & $1.84, \mathrm{~m} ; 1.30, \mathrm{~m}$ & 26.3 & $1.85, \mathrm{~m} ; 1.30, \mathrm{~m}$ \\
\hline 12 & 34.2 & $2.36(2 \mathrm{H}), \mathrm{m}$ & 33.0 & $2.29(2 \mathrm{H}), \mathrm{m}$ \\
\hline 13 & 45.5 & - & 45.9 & - \\
\hline 14 & 46.7 & - & 47.0 & - \\
\hline 15 & 47.3 & 2.44 , dd $(13.7,8.0) ; 2.11, \mathrm{~m}$ & 47.4 & 2.46 , dd $(13.9,7,5) ; 2.13, \mathrm{~m}$ \\
\hline 16 & 82.4 & $4.39, \mathrm{~m}$ & 82.6 & 4.43, dd $(6.8,1.6)$ \\
\hline 17 & 57.2 & $1.87, \mathrm{~m}$ & 57.6 & $1.91, \mathrm{~m}$ \\
\hline 18 & 18.8 & $1.22, \mathrm{~s}$ & 18.8 & $1.25, \mathrm{~s}$ \\
\hline \multirow[t]{2}{*}{19} & 29.1 & $0.49, \mathrm{~d}(3.9)$ & 28.5 & $0.55, \mathrm{~d}(4.0)$ \\
\hline & & $0.19, \mathrm{~d}(3.9)$ & & $0.22, \mathrm{~d}(4.0)$ \\
\hline 20 & 29.4 & $2.36, \mathrm{~m}$ & 29.8 & $2.40, \mathrm{~m}$ \\
\hline 21 & 17.4 & $1.00, \mathrm{~d}(6.5)$ & 17.7 & $1.04, \mathrm{~d}(6.4)$ \\
\hline 22 & 33.4 & $2.26 \mathrm{~m} ; 1.62, \mathrm{~m}$ & 33.7 & $2.28, \mathrm{~m} ; 1.64, \mathrm{~m}$ \\
\hline 23 & 28.6 & $2.06 \mathrm{~m} ; 1.83, \mathrm{~m}$ & 29.0 & $2.13 \mathrm{~m} ; 1.88, \mathrm{~m}$ \\
\hline 24 & 77.8 & $3.97, \mathrm{~m}$ & 78.3 & $3.98, \mathrm{~m}$ \\
\hline 25 & 72.8 & - & 72.9 & - \\
\hline 26 & 25.8 & $1.52, \mathrm{~s}$ & 26.0 & $1.54, \mathrm{~s}$ \\
\hline 27 & 25.8 & $1.52, \mathrm{~s}$ & 26.0 & $1.54, \mathrm{~s}$ \\
\hline 28 & 28.5 & $2.07, \mathrm{~s}$ & 28.3 & $1.94, \mathrm{~s}$ \\
\hline 29 & 16.4 & $1.39, \mathrm{~s}$ & 17.7 & $1.38, \mathrm{~s}$ \\
\hline 30 & 19.9 & $0.88, \mathrm{~s}$ & 20.0 & $0.97, \mathrm{~s}$ \\
\hline
\end{tabular}

3.3.2. 3-O- $\beta$-D-xylopyranosyl-6,16-di-O- $\beta$-D-glucopyranosyl-

$3 \beta, 6 \alpha, 16 \beta, 24(S)-25$ pentahydroxycycloartane dodecaacetate (1a)

Amorphous white solid; $\mathrm{C}_{73} \mathrm{H}_{106} \mathrm{O}_{32} ;[\alpha]^{23}{ }_{\mathrm{D}}+5.0(c 0.2 \mathrm{MeOH}) ; \mathrm{IR}$ $\nu^{\mathrm{KBr}}{ }_{\max } \mathrm{cm}^{-1}: 3435(>\mathrm{OH}), 2930(>\mathrm{CH}), 1680(\mathrm{C}=\mathrm{O})$; for ${ }^{1} \mathrm{H}$ and ${ }^{13} \mathrm{C} \mathrm{NMR}\left(\mathrm{CDCl}_{3}, 400 \mathrm{MHz}\right)$ data of the aglycone moiety and the sugar portion see Tables 1 and 2, respectively; HRESIMS $m / z$ 1533.6456 [M $+\mathrm{K}^{+}$(calcd. For $\mathrm{C}_{73} \mathrm{H}_{106} \mathrm{O}_{32} \mathrm{~K}$ 1533.6454) (positive mode). 
Table 2

${ }^{13} \mathrm{C}$ and ${ }^{1} \mathrm{H}$ NMR data $(\mathrm{J}$ in $\mathrm{Hz}$ ) of the sugar portions of 1 and 2 (400 MHzfor 2, and 500 $\mathrm{MHz}$ for $1, \delta \mathrm{ppm}$, in Pyridine- $\mathrm{d}_{5}$ ).

\begin{tabular}{|c|c|c|c|c|}
\hline \multirow[t]{2}{*}{$\mathrm{C} / \mathrm{H}$} & \multicolumn{2}{|l|}{1} & \multicolumn{2}{|l|}{2} \\
\hline & $\begin{array}{l}\delta_{C} \\
\beta \text {-D-Xyl (at C- } \\
3 \text { ) }\end{array}$ & $\delta_{\mathrm{H}}(J$ in $\mathrm{Hz})$ & $\begin{array}{l}\delta_{\mathrm{C}} \\
\beta-\mathrm{D}-\mathrm{Xyl}\end{array}$ & $\begin{array}{l}\delta_{\mathrm{H}}(J \text { in } \mathrm{Hz}) \\
(\text { at } \mathrm{C}-3)\end{array}$ \\
\hline 1 & 107.4 & $4.85, \mathrm{~d}(7.5)$ & 105.4 & $4.86, \mathrm{~d}(6.8)$ \\
\hline 2 & 75.3 & $4.05, \mathrm{t}(8.0)$ & 83.5 & $4.12, \mathrm{t}(7.6)$ \\
\hline 3 & 79.0 & $4.24, \mathrm{~m}$ & 77.2 & $4.20, \mathrm{t}(7.6)$ \\
\hline 4 & 71.6 & $4.14, \mathrm{~m}$ & 71.0 & $4.19, \mathrm{~m}$ \\
\hline \multirow[t]{2}{*}{5} & 66.7 & $\begin{array}{l}\text { 4.35, dd }(11.1,5.0) ; 3.69, \mathrm{t} \\
(10.6)\end{array}$ & 66.5 & $\begin{array}{l}3.60, \mathrm{~m} \\
4.29, \mathrm{~m}\end{array}$ \\
\hline & \multicolumn{4}{|c|}{$\beta$-D-Glc (at C-6) $\alpha$-L-Ara (at C-2 of Xyl) } \\
\hline 1 & 105.1 & $4.89, \mathrm{~d}(7.7)$ & 106.7 & $5.22, \mathrm{~d}(6.6)$ \\
\hline 2 & 75.4 & 4.00, dd $(8.5,7.5)$ & 73.7 & $4.61, \mathrm{dd}(7.2,4.8)$ \\
\hline 3 & 78.2 & $4.24, \mathrm{t}(9.0)$ & 74.3 & 4.23 , dd $(7.2,2.5)$ \\
\hline 4 & 71.0 & $4.23, \mathrm{t}(9.6)$ & 69.1 & $4.31, \mathrm{~m}$ \\
\hline 5 & 77.9 & $3.97, \mathrm{~m}$ & 67.1 & $\begin{array}{l}\text { 4.44, dd (12.0, } \\
3.2) \text {; } \\
3.82 \text {, d (11.4) }\end{array}$ \\
\hline \multirow[t]{2}{*}{6} & 62.8 & $\begin{array}{l}\text { 4.61, dd }(11.0,3.5) \\
4.36, \mathrm{~m}\end{array}$ & - & - \\
\hline & \multicolumn{4}{|c|}{$\beta$-D-Glc (at C-16) $\beta$-D-Glc (at C-6) } \\
\hline 1 & 106.3 & $4.73, \mathrm{~d}(7.7)$ & 105.4 & $4.91, \mathrm{~d}(7.7)$ \\
\hline 2 & 75.4 & $4.00, \mathrm{dd}(8.5,7.5)$ & 75.8 & $4.05, \mathrm{t}(8.4)$ \\
\hline 3 & 78.2 & $4.15, \mathrm{t}(9.0)$ & 79.2 & $4.24, \mathrm{~m}$ \\
\hline 4 & 71.7 & $4.14, \mathrm{t}(9.6)$ & 72.1 & $4.16, \mathrm{t}(7.6)$ \\
\hline 5 & 77.9 & $3.89, \mathrm{t}(6.3)$ & 78.0 & $3.97, \mathrm{t}(7.6)$ \\
\hline \multirow[t]{2}{*}{6} & 62.6 & $\begin{array}{l}4.56 \text {, dd }(11.0,3.0) \\
4.35 \text {, dd }(11.0,5.0)\end{array}$ & 63.3 & $\begin{array}{l}4.60 \text {, dd }(7.6,2.2) \text {; } \\
4.37, \mathrm{~m}\end{array}$ \\
\hline & & & \multicolumn{2}{|c|}{$\beta$-D-Glc (at C-16) } \\
\hline 1 & & & 106.6 & $4.75, \mathrm{~d}(7.6)$ \\
\hline 2 & & & 75.7 & 3.99 , dd $(7.6,4.8)$ \\
\hline 3 & & & 78.6 & $4.17, \mathrm{t}(6.8)$ \\
\hline 4 & & & 72.0 & $4.14, \mathrm{t}(6.8)$ \\
\hline 5 & & & 78.2 & $3.90, \mathrm{~m}$ \\
\hline 6 & & & 62.9 & $\begin{array}{l}4.55 \text { dd (11.2, } \\
1.6) ; \\
4.37, \mathrm{~m}\end{array}$ \\
\hline
\end{tabular}

3.3.3. 3-O-[ $\alpha$-L-arabinopyranosyl- $(1 \rightarrow 2)-\beta-D-x y l o p y r a n o s y l]-6-O-\beta-D-$ glucopyranosyl-16-O- $\beta$-D-glucopyranosyl-3 $\beta, 6 \alpha, 16 \beta, 24(S)-25-$ pentahydroxycycloartane (2)

Amorphous white solid; $\mathrm{C}_{52} \mathrm{H}_{88} \mathrm{O}_{23}[\alpha]^{23}{ }_{D}+15.0$ (c $\left.0.2 \mathrm{MeOH}\right)$; IR ${ }_{\nu}{ }_{\text {max }}^{\mathrm{KBr}} \mathrm{cm}^{-1}$ : $3445(>\mathrm{OH}), 2920(>\mathrm{CH})$; for ${ }^{1} \mathrm{H}$ and ${ }^{13} \mathrm{C}$ NMR (Pyridine- $\mathrm{d}_{5}, 400 \mathrm{MHz}$ ) data of the aglycone moiety and the sugar portion see Tables 1 and 2, respectively; HRESIMS $m / z 1103.5648$ [M $+\mathrm{Na}]^{+}$(calcd. for $\mathrm{C}_{52} \mathrm{H}_{88} \mathrm{O}_{23} \mathrm{Na}, 1103.5646$ ) (positive mode). The structure of compound 2 and key HMBCs $(\mathrm{H} \rightarrow \mathrm{C})$ is shown in Fig. 2.

\subsection{Acid hydrolysis}

The crude saponin mixture of fraction $\mathrm{P}(1 \mathrm{~g})$ was heated at $60{ }^{\circ} \mathrm{C}$ with 1:1 $0.5 \mathrm{~N} \mathrm{HCl}$-dioxane $(3 \mathrm{~mL})$ for $2 \mathrm{~h}$, and then evaporated in vacuo. The solution was partitioned with EtOAc, and the $\mathrm{H}_{2} \mathrm{O}$ layer was neutralized with $0.5 \mathrm{M} \mathrm{NaOH}$. After gaining the hydrolysed mixture, three monosaccharides were purified utilizing normal-phase silica gel as stationary phase $(35 \times 120 \mathrm{~mm}, 55 \mathrm{~g})$ eluting with $\mathrm{CHCl}_{3}-\mathrm{MeOH}$ $\mathrm{H}_{2} \mathrm{O}$ solvent system (95:5:0.5, 80:20:1, 80:20:2; 70:30:3; 61:32:7). After purification, the obtained sugar units were identified by comparison with authentic samples using TLC in $\mathrm{CHCl}_{3}-\mathrm{MeOH}-\mathrm{H}_{2} \mathrm{O}$ (60:40:10) system and their identity was confirmed after preparative TLC in the same solvent. The optical rotation of each purified sugar was measured to afford L-arabinose $\left([\alpha]^{20}{ }_{D}+70.0, c 0.1, \mathrm{H}_{2} \mathrm{O}\right), \mathrm{D}$-xylose $\left([\alpha]^{20}{ }_{\mathrm{D}}\right.$ $\left.+22.0, c 0.1, \mathrm{H}_{2} \mathrm{O}\right)$ and D-glucose $\left([\alpha]^{20}{ }_{\mathrm{D}}+13.0, c 0.1, \mathrm{H}_{2} \mathrm{O}\right)$.
Table 3

Hemolytic activities of butanolic-, methanolic extracts and compounds 1, 1a and 2 from A. brachycalyx ${ }^{\mathrm{a}, \mathrm{b}, \mathrm{c}}$

\begin{tabular}{|c|c|c|c|}
\hline Group & Absorbance value & Hemolytic activity & $\begin{array}{l}\text { Hemolytic percentage } \\
(\%)\end{array}$ \\
\hline Saline & $0.110 \pm 0.0009$ & $0.000 \pm 0.002$ & $0.00 \pm 0.23$ \\
\hline Distillated water & $0.638 \pm 0.004$ & $1.00 \pm 0.001 * *$ & $100.03 \pm 0.10^{* *}$ \\
\hline \multicolumn{4}{|l|}{ AST VII $(\mu \mathrm{g} / \mathrm{mL})$} \\
\hline 5000 & $0.203 \pm 0.0008$ & $0.16 \pm 0.01^{*}$ & $16.54 \pm 1.89^{*}$ \\
\hline 500 & $0.155 \pm 0.002$ & $0.085 \pm 0.004$ & $8.51 \pm 0.43$ \\
\hline 250 & $0.124 \pm 0.004$ & $0.027 \pm 0.0010$ & $2.71 \pm 0.10$ \\
\hline 125 & $0.123 \pm 0.006$ & $0.023 \pm 0.0016$ & $2.39 \pm 0.16$ \\
\hline 50 & $0.121 \pm 0.002$ & $0.014 \pm 0.005$ & $1.47 \pm 0.50$ \\
\hline 25 & $0.111 \pm 0.005$ & $0.014 \pm 0.001$ & $1.41 \pm 0.12$ \\
\hline 12.5 & $0.111 \pm 0.001$ & $0.018 \pm 0.002$ & $0.18 \pm 0.28$ \\
\hline 2.5 & $0.873 \pm 0.002$ & $-0.04 \pm 0.004$ & $-4.35 \pm 0.47$ \\
\hline \multicolumn{4}{|l|}{ QS-21 $(\mu \mathrm{g} / \mathrm{mL})$} \\
\hline 5000 & $2.573 \pm 0.002$ & $4.66 \pm 0.005^{* *}$ & $466 \pm 0.50^{* *}$ \\
\hline 500 & $0.854 \pm 0.009$ & $1.65 \pm 0.008 * *$ & $165 \pm 0.82^{* *}$ \\
\hline 250 & $0.873 \pm 0.005$ & $1.35 \pm 0.001 * *$ & $135 \pm 1.34 * *$ \\
\hline 125 & $0.984 \pm 0.003$ & $1.44 \pm 0.002 * *$ & $144 \pm 0.21^{* *}$ \\
\hline 50 & $0.785 \pm 0.003$ & $1.40 \pm 0.008 * *$ & $140 \pm 0.89^{* *}$ \\
\hline 25 & $0.514 \pm 0.001$ & $1.27 \pm 0.02 *$ & $127.87 \pm 2.41 *$ \\
\hline 12.5 & $0.342 \pm 0.005$ & $0.76 \pm 0.01 *$ & $76.58 \pm 1.24^{*}$ \\
\hline 2.5 & $0.155 \pm 0.001$ & $-0.08 \pm 0.004 *$ & $-8.880 \pm 0.43^{*}$ \\
\hline \multicolumn{4}{|c|}{ Compound $1(\mu \mathrm{g} / \mathrm{mL})$} \\
\hline 5000 & $0.802 \pm 0.000$ & $1.30 \pm 0.001^{* * *}$ & $130.91 \pm 1.18^{* * *}$ \\
\hline 500 & $0.160 \pm 0.004$ & $0.09 \pm 0.010^{*}$ & $9.38 \pm 1.00 *$ \\
\hline 250 & $0.156 \pm 0.003$ & $0.08 \pm 0.008$ & $8.63 \pm 0.82$ \\
\hline 125 & $0.135 \pm 0.001$ & $0.047 \pm 0.002$ & $4.71 \pm 0.28$ \\
\hline 50 & $0.131 \pm 0.003$ & $0.01 \pm 0.007$ & $1.88 \pm 0.75$ \\
\hline 25 & $0.118 \pm 0.004$ & $0.015 \pm 0.001$ & $1.50 \pm 0.10$ \\
\hline 12.5 & $0.116 \pm 0.001$ & $0.011 \pm 0.003$ & $1.12 \pm 0.39$ \\
\hline 2.5 & $0.103 \pm 0.003$ & $-0.134 \pm 0.007$ & $-1.33 \pm 0.78$ \\
\hline \multicolumn{4}{|c|}{ Compound 1a $(\mu \mathrm{g} / \mathrm{mL})$} \\
\hline 5000 & $2.154 \pm 0.001$ & $3.84 \pm 0.002^{* *}$ & $384.98 \pm 0.28^{* *}$ \\
\hline 500 & $0.152 \pm 0.002$ & $0.08 \pm 0.004$ & $8.01 \pm 0.47$ \\
\hline 250 & $0.126 \pm 0.002$ & $0.030 \pm 0.005$ & $3.09 \pm 0.54$ \\
\hline 125 & $0.126 \pm 0.002$ & $0.030 \pm 0.005$ & $3.09 \pm 0.54$ \\
\hline 50 & $0.121 \pm 0.002$ & $0.02 \pm 0.005$ & $2.01 \pm 0.50$ \\
\hline 25 & $0.111 \pm 0.002$ & $0.001 \pm 0.006$ & $0.12 \pm 0.68$ \\
\hline 12.5 & $0.103 \pm 0.003$ & $-0.126 \pm 0.008$ & $-1.26 \pm 0.89$ \\
\hline 2.5 & $0.103 \pm 0.003$ & $-0.013 \pm 0.007$ & $-1.32 \pm 0.78$ \\
\hline \multicolumn{4}{|c|}{ Compound $2(\mu \mathrm{g} / \mathrm{mL})$} \\
\hline 5000 & $0.194 \pm 0.002$ & $0.15 \pm 0.006^{*}$ & $15.95 \pm 0.66^{*}$ \\
\hline 500 & $0.158 \pm 0.003$ & $0.09 \pm 0.007$ & $9.13 \pm 0.78$ \\
\hline 250 & $0.148 \pm 0.000$ & $0.07 \pm 0.001$ & $7.18 \pm 0.10$ \\
\hline 125 & $0.137 \pm 0.009$ & $0.05 \pm 0.002$ & $5.16 \pm 0.21$ \\
\hline 50 & $0.118 \pm 0.004$ & $0.01 \pm 0.009$ & $1.51 \pm 0.09$ \\
\hline 25 & $0.110 \pm 0.008$ & $-0.0008 \pm 0.001$ & $-0.75 \pm 0.18$ \\
\hline 12.5 & $0.0733 \pm 0.004$ & $-0.07 \pm 0.01$ & $-7.01 \pm 1.09$ \\
\hline 2.5 & $0.089 \pm 0.001$ & $-0.040 \pm 0.006$ & $-3.82 \pm 0.61$ \\
\hline \multicolumn{4}{|l|}{$\delta_{\mathrm{H}}(J$ in $\mathrm{Hz})$} \\
\hline 5000 & $0.193 \pm 0.003$ & $0.15 \pm 0.007^{*}$ & $15.76 \pm 0.76^{*}$ \\
\hline 500 & $0.133 \pm 0.002$ & $0.04 \pm 0.006$ & $4.27 \pm 0.68$ \\
\hline 250 & $0.126 \pm 0.001$ & $0.03 \pm 0.002$ & $3.20 \pm 0.21$ \\
\hline 125 & $0.118 \pm 0.001$ & $0.01 \pm 0.003$ & $1.43 \pm 0.32$ \\
\hline 50 & $0.115 \pm 0.008$ & $0.008 \pm 0.001$ & $0.87 \pm 0.18$ \\
\hline 25 & $0.109 \pm 0.001$ & $-0.002 \pm 0.003$ & $-0.26 \pm 0.32$ \\
\hline 12.5 & $0.099 \pm 0.004$ & $-0.02 \pm 0.001$ & $-2.03 \pm 0.10$ \\
\hline 2.5 & $0.089 \pm 0.001$ & $-0.04 \pm 0.003$ & $-4.05 \pm 0.32$ \\
\hline \multicolumn{4}{|c|}{ Butanol Extract $(\mu \mathrm{g} / \mathrm{mL})$} \\
\hline 5000 & $0.487 \pm 0.008$ & $0.68 \pm 0.018^{* *}$ & $71.41 \pm 1.89^{* *}$ \\
\hline 500 & $0.142 \pm 0.002$ & $0.61 \pm 0.004$ & $6.10 \pm 0.47$ \\
\hline 250 & $0.131 \pm 0.002$ & $0.03 \pm 0.005$ & $3.89 \pm 0.50$ \\
\hline 125 & $0.122 \pm 0.001$ & $0.02 \pm 0.003$ & $2.19 \pm 0.37$ \\
\hline 50 & $0.120 \pm 0.009$ & $0.01 \pm 0.002$ & $1.94 \pm 0.21$ \\
\hline 25 & $0.102 \pm 0.002$ & $-0.01 \pm 0.004$ & $-1.46 \pm 0.47$ \\
\hline 12.5 & $0.093 \pm 0.004$ & $-0.03 \pm 0.001$ & $-3.16 \pm 0.10$ \\
\hline 2.5 & $0.088 \pm 0.001$ & $-0.04 \pm 0.002$ & $-4.11 \pm 0.28$ \\
\hline
\end{tabular}

$\mathrm{a} * \mathrm{p}<0.05 ; * * \mathrm{p}<0.01 ; * * \mathrm{p}<0.001$

${ }^{\mathrm{b}}$ Hemolytic percents of saline and distilled water were included as minimal and maximal hemolytic control.

${ }^{\mathrm{c}}$ All values represent the mean \pm standard deviation (n $1 / 43$ test). 


\subsection{Biological evaluation}

\subsubsection{Measurement of the effects on cytokine biosynthesis}

Heparinized peripheral human whole blood from healthy volunteers were stimulated with $50 \mathrm{ng}$ PMA (Sigma, St. Lois, MO, U.S.A.) plus $400 \mathrm{ng}$ ionomycin (Sigma, St. Lois, MO, U.S.A.) for IL-2, IFN- $\gamma$ and IL$17 \mathrm{~A}$ and incubated in the presence of test samples or reference compounds QS-21 and AST VII for $48 \mathrm{~h}$. The cultured supernatants were collected and the concentration of the cytokines produced by macrophages or lymphocytes were measured using a commercially available enzyme-linked immunosorbent assay (ELISA) (eBioscience, Vienne, Austria). The assays were performed according to the manufacturer's recommendations. The average absorbance readings of the samples were then compared with the concentrations of the standard curve, and the samples concentration of each cytokine was calculated. The results of IL-2, IFN- $\gamma$ and IL-17A were expressed as picograms per milliliter. The minimum detection limits were $9.1 \mathrm{pg} / \mathrm{mL}, 0.99 \mathrm{pg} / \mathrm{mL}$, and $0.5 \mathrm{pg} / \mathrm{mL}$ for IL-2, IFN- $\gamma$ and IL-17A, respectively. Diluted supernatants were used for all assays and each assay was performed in triplicate.

\subsubsection{Peripheral whole-blood cultures}

Human whole blood (containing $20 \mathrm{U} / \mathrm{mL}$ heparine) was suspended in RPMI-1640 medium supplemented with\%10 FBS, $100 \mathrm{U} / \mathrm{mL}$ penicillin and $100 \mathrm{mg} / \mathrm{mL}$ streptomycin in a 1:10 ratio. PMA $(50 \mathrm{ng} / \mathrm{mL})$ and ionomycin $(400 \mathrm{ng} / \mathrm{mL})$ were added to the whole blood for stimulation of immune system cells. The samples were dissolved as stock solution in DMSO at concentration of $5 \mathrm{mg} / \mathrm{mL}$ and DMSO was used as negative control. An amount of $1 \mathrm{~mL}$ of the heparinized blood which was stimulated by PMA ( $50 \mathrm{ng} / \mathrm{mL})$ and ionomycin $(400 \mathrm{ng} / \mathrm{mL})$ was transferred into each well of 24-well plate and incubated at $37^{\circ} \mathrm{C}$ for 48 in the absence or presence of 3 or $6 \mu \mathrm{g} / \mathrm{mL}$ concentrations of samples or QS-21 and AST VII as reference compound. The diluted culture supernatants were then mixed with sample dilent at 1:2 ratio and were assayed using the specific ELISA method for IL-2, IFN- $\gamma$ and IL-17A (Lenarczyk et al., 2000; Nalbantsoy et al., 2011). The protocol was approved by the Human Ethics Committee of Ege University, and all of the used procedures conformed to the protocol was approved by the Human Ethics Committee of Ege University, and all of the procedures used conformed to the declaration of Helsinki. The subjects were informed about the procedures and signed the informed consent forms (approval number 15-11/19).

\subsubsection{Hemolytic activity assay}

Hemolytic activity of the molecules was measured according to Nalbantsoy et al. (2011) with some modifications. Red blood cells obtained from human healthy volunteers. Blood was collected with BD Vacutainer TM (NH 143 I. U., Belliver Industrial Estate, Plymouth, UK). An amount of $7 \mathrm{~mL}$ of blood was washed three times using sterile saline solution $(0.89 \%, \mathrm{w} / \mathrm{v} \mathrm{NaCl}$, pyrogen free) and then it was centrifuged at $2000 \times g$ for $5 \mathrm{~min}$. The final cell suspension was prepared by diluting the pellet to $0.5 \%$ using saline solution. A volume of $0.01 \mathrm{~mL}$ of the cell suspension was mixed in $\mathrm{U}$ button 96-well microplate with $0.05 \mathrm{~mL}$ diluents containing $2.5,12.5,25,50,125,250,500$ and $5000 \mu \mathrm{g} / \mathrm{mL}$ concentrations of molecules in saline solutions. The mixtures were incubated for $30 \mathrm{~min}$ at $37{ }^{\circ} \mathrm{C}$ and centrifuged at $800 \times g$ for $10 \mathrm{~min}$. The free hemoglobin in the supernatants was measured spectrophotometrically at $412 \mathrm{~nm}$. Saline solution and distilled water were used as minimal and maximal hemolytic controls. The hemolytic percent developed by the saline control was subtracted from all groups. Each experiment included triplicates at each concentration.

\subsubsection{Statistical analysis}

The data were expressed as mean \pm standard deviation (S.D.) and examined for their statistical significance of difference with Student $t$ test, One-way ANOVA and the post hoc test Tamhane's and dunnet (depends on homogeneity and normality of the absorbance values) using SPSS 16.0. P-values less than $0.05,0.01$ and 0.001 were considered to be statistically significant.

\section{Acknowledgements}

The authors gratefully acknowledge to the financial support of Ege University Research Foundation (15-FBE-001) for the finical support and thank Prof. Dr. Ali Asghar Maassoumi for the identification of the plant material, and special thanks to NMR operators of both Ege University and Prince Sattam bin Abdulaziz University namely Salih Günnaz and Anzarul Haque, respectively.

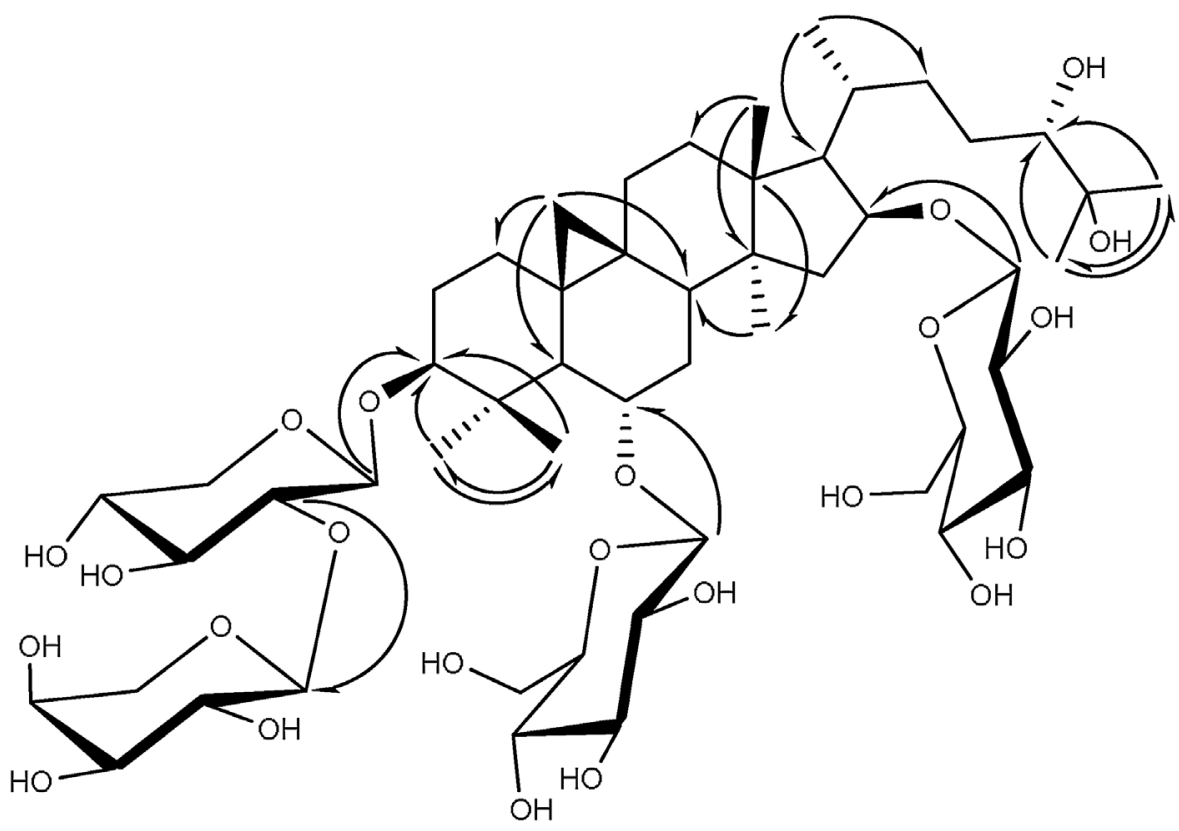

Fig. 2. Key long-range correlations [HMBCs $(\mathrm{H} \rightarrow \mathrm{C})]$ of $\mathbf{2}$. 


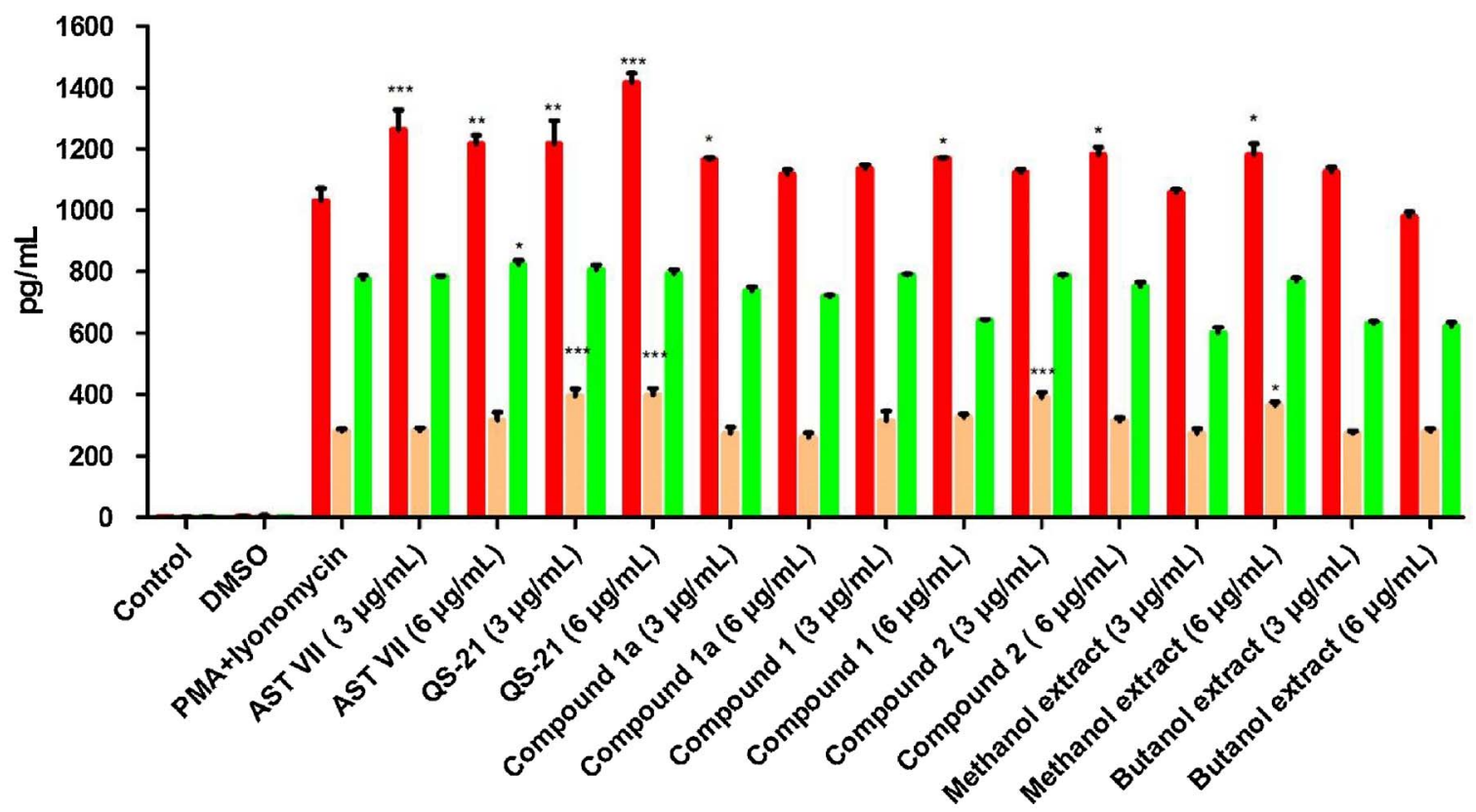

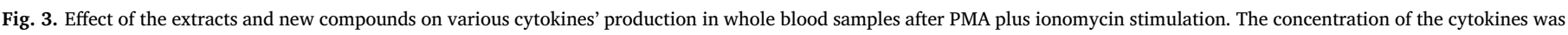

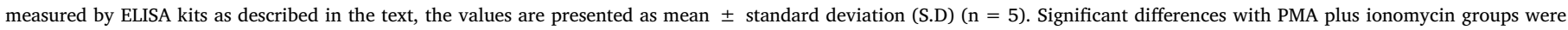
designated as ${ }^{*} P<0.05$, ${ }^{*} P<0.01$ and ${ }^{* * *} P<0.001$.

\section{Appendix A. Supplementary data}

Supplementary data associated with this article can be found, in the online version, at http://dx.doi.org/10.1016/j.phytol.2017.05.028.

\section{References}

Aggarwal, S., Gurney, A.L., 2002. IL-17: prototype member of an emerging cytokine family. J. Leukoc. Biol. 71, 1-8.

Bedir, E., Calıs, I., Aquino, R., Piacente, S., Pizza, C., 1998. Cycloartane triterpene glycosides from the roots of Astragalus brachypterus and Astragalus microcephalus. J. Nat. Prod. 61, 1469-1472.

Bedir, E., Calis, I., Aquino, R., Piacente, S., Pizza, C., Trojanoside, H., 1999. A cycloartanetype glycoside from the arial parts of Astragalus trojanus. Phytochemistry 51, 1017-1020.

Bedir, E., Pugh, N., Calis, I., Pasco, D.S., Khan, I.A., 2000. Immunostimulatory effects of cycloartane-type triterpene glycosides from Astragalus species. Biol. Pharm. Bull. 23, 834-837.

Behboudi, S., Morein, B., Villacres-Eriksson, M.C., 1999. Quillaja saponin formulations that stimulate proinflammatory cytokines elicit a potent acquired cell-mediated immunity. Scand. J. Immunol. 50, 371-377.

Ben-Asouli, Y., Banai, Y., Pel-Or, Y., Shir, A., Kaempfer, R., 2002. Human interferongamma mRNA autoregulates its translation through a pseudoknot that activates the interferon-inducible protein kinase PKR. Cell 108, 221-232.

Bissinger, R., Modicano, P., Alzoubi, K., Honisch, S., Faggio, C., Abed, M., Lang, F., 2014. Effect of saponin on erythrocytes. Int J. Hematol. 100, 51-59.

Calis, I., Yuruker, A., Tasdemir, D., Wrigh, A.D., Sticher, O., Luo, Y.D., Pezzuto, J.M. 1997. Cycloartane triterpene glycosides from the roots of Astragalus melanophrurius. Planta Med. 63, 183-186.

Fox, C.B., 2009. Squalene emulsions for parenteral vaccine and drug delivery. Molecules 14, 3286-3312.

Gülcemal, D., Alankus-Calışkan, O., Perrone, A., Ozgökce, F., Piacente, S., Bedir, E., 2011. Cycloartane glycosides from Astragalus aureus. Phytochemistry 72, 761-768.

Gan, L., Han, X., Chen, Y., 1986. The chemical investigation of Astragalus sieversianus pall. part 2. astrasieversianins IX, XI and XV, cycloartane derived saponins from Astragalus sieversianus. Phytochemistry 25, 1437-1441.

Gillis, S., Williams, D., 1998. Cytokine therapy: lessons learned and future challenges. Curr. Opin. Immunol. 10, 501-503.

Horo, I., Bedir, E., Perrone, A., Ozgökce, F., Piacente, S., Alankuş-Calişkan, O., 2010. Triterpene glycosides from Astragalus icmadophilus. Phytochemistry 71, 956-973.

Hu, Y., Mao, A., Tan, Y., Zhao, Y., He, K., 2016. Role of 5 saponins in secretion of cytokines by PRRSV-induced endothelial cells. Drug Res 66, 357-362.

Isaev, M.I., Imomnazarov, B.A., Fadeev, Y.M., Kintya, P.A., 1992. Triterpene glycosides of Astragalus and their genins:XLII Cycloartanes of Astragalus tragacantha. Khim. Prir.
Soedin. 3, 360-367.

Isaev, M.I., 1991. Triterpene glycosides of Astragalus and their genins XXXIX:Cycloaraloside D from Astragalus amarus. Chem. Nat. Compd. 27, 457-459.

Kitagawa, I., Wang, H.K., Takagi, A., Fuchida, M., Miura, I., Yoshikawa, M., 1983a. Saponin and Sapogenol.XXXVI. Chemical constituents of astragali radix the Root of Astragalus membranaceus BUNGE. (1). Cycloastragenolthe 9,19-Cycloanostane-type aglycone of Astragalosides, and the artifact aglycone astragenol. Chem. Pharm. Bull. 31, 689-697.

Kitawaga, I., Wang, H.K., Saito, M., Yoshikawa, M., 1983b. Saponin and sapogenol. XXXVII. Chemical constituents of astragali radix:the root of Astragalus membranaceus Bunge. (4). Astragaloside VII and VIII. Chem. Pharm. Bull. 31, 716-722.

Lenarczyk, A., Helsloot, J., Farmer, K., Peters, L., Sturgess, A., Kirkham, B., 2000. Antigen-induced IL-17A response in the peripheral blood mononuclear cells (PBMC) of healthy controls. Clin. Exp. Immunol. 122, 4-18.

Li, X.Y., 2000. Immunomodulating components from Chinese medicines. Pharm. Biol. 38, $33-40$.

Liao, W., Lin, J.X., Leonard, W.J., 2011. IL-2 family cytokines: new insights into the complex roles of IL-2 as a broad regulator of T helper cell differentiation. Curr. Opin. Immunol. 23, 598-604.

Lin, F.C., Young, H.A., 2013. The talented interferon-gamma. Adv. Biosci. Biotechnol. 4, 6-13.

Massoumi, A.A., 1998. Old World Check List of Astragalus, fourth ed. Research Institute of Forests and Rangeland, Iran.

Nalbantsoy, A., Nesil, T., Erden, S., Calıs, I., Bedir, E., 2011. Adjuvant effects of Astragalus saponins macrophyllosaponin B and astragaloside VII. J. Ethnopharmacol. 134, 897-903.

Nalbantsoy, A., Nesil, T., Yılmaz-Dilsiz, O., Aksu, G., Khan, S.H., Bedir, E., 2012. Evaluation of the immunomodulatory properties in mice and in vitro anti-inflammatory activity of cycloartane type saponins from Astragalus species. J. Ethnopharmacol. 139, 574-581.

Oda, K., Matsuda, H., Murakami, T., Katayama, S., Ohgitani, T., Yoshikawa, M., 2003. Relationship between adjuvant activity and amphipathic structure of soya saponins. Vaccine 21, 2145-2215.

Ozipek, M., Donmez, A.A., Calis, I., Brun, R., Ruedi, P., Tasdemir, D., 2005. Leishmanicidal cycloartane-type triterpene glycosides from Astragalus oleifolius. Phytochemistry 66, 1168-1173.

Pandey, A., Rizvi, M., Ali Shah, B., Bani, S., 2016. Anti-arthritogenic effect of Saponin-1 by alteration of Th1/Th2 cytokine paradigm in arthritic mice. Cytokine 79, 103-113.

Polat, E., Bedir, E., Perrone, A., Piacente, S., Alankus-Caliskan, O., 2010. Triterpenoid saponins from Astragalus wiedemannianus ischer. Phytochemistry 71, 658-662.

Ranjbar, M., Karamian, R., 2002. Astragalus sect. Astragalus (Fabaceae) in Iran:complementary notes with a key to the species. Nordic. J. Bot. 2, 177-181.

Rios, J.L., Waterman, P.G., 1997. A review of the pharmacology and toxicology of Astragalus. Phytother. Res. 11, 411-418.

Rouvier, E., Luciani, M., Mattéi, M., Denizot, F., Golstein, P., 1993. CTLA-8, cloned from an activated T cell, bearing AU-rich messenger RNA instability sequences, and 
homologous to a herpesvirus saimiri gene. J. Immunol. 150, 5445-5456.

Savran, T., Gülcemal, D., Masullo, M., Karayıldırım, T., Polat, E., Piacente, S., AlankuşÇalışkan, Ö., 2012. Cycloartane glycosides from Astragalus erinaceus. Rec. Nat. Prod. 6, 230-236.

Schroder, K., Hertzog, P.J., Ravasi, T., Hume, D.A., 2004. Interferon-gamma: an overview of signals, mechanisms and functions. J. Leukoc .Biol. 75, 163-189.

Verotta, L., Guerrini, M., El-Sebakhy, N.A., Asaad, A.M., Toaima, S.M., Abou-Sheer, M.E., Luo, Y.D., Rezzuto, J.M., 2001. Cycloartane saponins from Astragalus peregrinus as modulators of lymphocyte proliferation. Fitoterapia 72, 894-905.

Yang, Z.G., Suna, H.X., Fang, W.H., 2005. Hemolytic activities and adjuvant effect of Astragalus membranaceus saponins (AMS) on the immune responses to ovalbumin in mice. Vaccine 23, 5196-5203.

Yang, X.O., Chang, S.H., Park, H., Nurieva, R., Shah, B., Acero, L., Wang, Y.H., Schluns, K.S., Broaddus, R.R., Zhu, Z., Dong, C., 2008. Regulation of inflammatory responses by IL-17F J. Exp. Med . 205, 1063-1075.

Yesilada, E., Bedir, E., Calis, I., Takaishi, Y., Ohmoto, Y., 2005. Effects of triterpene saponins from Astragalus species on in vitro cytokine release. J. Ethnopharmacol. 96, $71-77$.

Zhou, L., Shi, Y.-L., Li, K., Hamzavi, I., Gao, T.W., Huggins, R.H., Lim, H.W., Mi, Q.S., 2015. Increased circulating Th17 cells and elevated serum levels of TGF-beta and IL21 are correlated with human non-segmental vitiligo development. Pigment. Cell. Melanoma. Res. 28, 324-329. 